\title{
The Labour Market in \\ the New Information Economy
}

Richard B. Freeman

October 2002 


\begin{abstract}
The extension of information and communication technologies to economic activity is changing the labour market in important ways. This article shows that computerization and use of the Internet are associated with greater hours worked as well as higher wages; that IT occupations are rapidly increasing their share of employment; that job search and recruitment are moving rapidly to the Web, with consequences for matching employers and employees; and possibly most important of all, that trade unions have begun to use the Internet as a tool for servicing members and carrying their message to the public, raising the possibility of a major change in the nature of the union movement.
\end{abstract}

This paper was produced as part of the Labour Markets Programme. The Centre for Economic Performance is financed by the Economic and Social Research Council.

\title{
Acknowledgements
}

Richard B. Freeman is a Senior Research Fellow of the Labour Markets Programme at the Centre for Economic Performance, London School of Economics. He is also Professor of Economics at Harvard University and Programme Director of Labor Studies at NBER.

Published by

Centre for Economic Performance

London School of Economics and Political Science

Houghton Street

London WC2A $2 \mathrm{AE}$

All rights reserved. No part of this publication may be reproduced, stored in a retrieval system or transmitted in any form or by any means without the prior permission in writing of the publisher nor be issued to the public or circulated in any form other than that in which it is published.

Requests for permission to reproduce any article or part of the Working Paper should be sent to the editor at the above address.

(C) Richard B. Freeman, submitted 2002

ISBN 0753016362

Individual copy price: $£ 5$ 


\section{Introduction}

The "new economy", broadly defined by the extension of information and communication technologies (ICT or IT), particularly the Internet, to economic activity, is changing the labour market. ${ }^{1}$ The advent of IT has shifted demand for labour toward workers with skills complementing the new technologies. The low cost of transmitting information over the Internet is shifting job search and recruitment activities to the Web. The ease of communicating and interacting over the Internet has led unions to experiment with web-based modes of servicing members and carrying their message to the wider public. The new technologies, together with other important changes such as the continued increase in the educational attainment of the work force, shift of employment to service sectors, and increased employment of women, is producing a labour market that differs greatly from the industrial labour market that characterized the $20^{\text {th }}$ Century.

This paper examines some of the impacts of the information economy on the labour market. It shows that IT and the Internet are found at an increasing proportion of work places, with consequences for wages and hours worked, and are affecting job recruitment and collective worker activity. Since the adoption of IT technologies varies by country and sector, the developments of concern are "emerging ones" most readily seen in the US and other advanced OECD countries where Internet access is substantial and in the high-tech sectors within those countries. The focus is thus on leading sectors and recent trends rather than on average activities.

To see how IT and the Internet affect hours and wages, I estimate the relationship between computer use and Internet use at work and hours worked and hourly earnings. Workers who use computers and/or the Internet at work report more hours worked than workers with comparable demographic characteristics who do not use computers or the Internet. Because some workers use the Internet for leisure at work while others use the Internet to work at home, however, this does not yield the full effect of the Internet and computerization on hours worked. New surveys or time budget studies will be needed to assess the full effect of the Internet on work. Previous research (Autor et al., 1998; Krueger,

\footnotetext{
${ }^{1}$ The term new economy has diverse meanings and definitions. I follow the US Department of Commerce definition "an economy in which IT and related investments drive higher rates of productivity growth" ... and where "IT-related changes in the organization of production and the composition of employment also support atypically high rates of productivity growth in periods of economic slowdown" (US Department of Commerce, Digital Economy 2002, p v.)
} 
1993) has found that computer use is positively associated with hourly earnings. My analysis confirms the positive link between computer use and hourly earnings in data for the early 2000s and finds a similar positive link between Internet use and hourly earnings.

Surveys of web use show that many workers use the Internet to search for jobs and that many employers post their jobs at Internet recruitment sites or on their home page. Because the Internet is a low cost medium for transmitting information, the Internet recruitment business has been one of the few dot.com successes on the Web. I explore the possibility that the shift of job search and recruitment to the Internet could lower the "NAIRU", particularly in the European Union, where spells of joblessness are much longer than in the US. I argue that such an effect is uncertain because the lower cost of search could also induce workers to search over more jobs and firms to review more applicants, increasing time searched. The strongest prediction about the macro-economic impact of the Internet's becoming a medium for job search and recruitment is that it will produce better matches.

Finally, I find that the Internet is changing the way trade unions operate in several important areas. The Internet and IT allow unions to provide customised services to members; to improve the flow of labour news around the world, potentially producing a new internationalism among activists; to organize workers over the Web outside of workplaces; to conduct disputes with employers by providing information on issues without the intervention of the media; and to improve union democracy. I give examples of innovative union activity in each of these areas and assess the possibility that by following these and related opportunities unions will be able to reverse their long run decline in membership and influence, albeit in a new "e-union" form.

\section{IT and Computerization of Work}

The development of IT and the Internet have been heralded as creating a new economy in the US, where digital technology allows labour productivity to grow at faster rates than in the past; where inflation is negligible, where unemployment is below rates in the EU; and where labour market flexibility speeds the adjustment and adaptation process. While the notion that computerization was the driver of 1990s economic outcomes has become conventional wisdom, the evidence is more problematic (Card and DiNardo, 2002). At the minimum, the 
dot.com failures and stock market collapses of the early 2000s raise questions about the ratio of hype to reality in the new economy talk. ${ }^{2}$ Regardless of how one stands on the long term impact of IT on the economy, however, there is no gainsaying that the IT sectors of the economy have grown and that a majority of workplaces have come to use computers and the Internet as normal operating technologies.

Table 1 presents data on the growth of IT industries and occupations and on workers' use of computers and the Internet at work in the US in the 1990s. Line 1 shows that employment in IT producing industries increased in from approximately $3.3 \%$ of total employment in 1992 to $4.3 \%$ of total employment in 2000. Indicative of the demand pressures behind these figures, the earnings of workers in IT-producing sectors rose from 1.65 times the earnings of workers throughout the economy in 1992 to 2.11 times the earnings of all workers in 2000 (US Department of Commerce Digital Economy 2002, Appendix, table A-5.2) Line 2 shows that employment also increased rapidly in IT occupations, from $4 \%$ in 1992 to $5.1 \%$ in 2000, though changes in definitions of occupations due to the rise of new IT work weakens comparability over time. ${ }^{3}$ By contrast, line 3 tells a very different story about employment in industries that made the biggest investments in IT over the period, measured by spending on IT equipment per full time equivalent worker. Employment grew by $1.8 \%$ in industries in the top half of the distribution of IT using industries but grew by $2.2 \%$ in industries in the bottom half of the distribution Even though, IT-using sectors increased their share of GDP, their greater productivity growth shifted employment into less IT intensive industries. ${ }^{4}$ Even so, however, lines 4 and 5 show a substantial trend in computer and Internet use at work. In $200156 \%$ of workers aged 18 to 65 said that they used a computer at work compared to just $25 \%$ in 1984 . The rise in Internet use is sharper, from 17 percent in 1997 to $41 \%$ in 2001.

The widespread use of computers at work is concentrated among white collar workers, particularly managers and professionals. These workers use computers for e-mail over the Internet, for word-processing, for spreadsheet and data base analysis, and for

\footnotetext{
${ }^{2}$ The rhetoric surrounding the New Economy is impressive. Consider "the New Economy ... is the kind of profound transformation of all industries that happens perhaps twice a century ... comparable to the rise of the manufacturing economy in the 1890s and the emergence of the mass-production corporate economy in the 1940s and 1950s" (PPI, p 3)

3 The BLS added several IT occupations to the Standard Occupational Classification in 2000 and reorganized its clas sifications of others.

${ }^{4}$ The rate of productivity growth in the high IT industries was $2.5 \%$ per year compared to $0.5 \%$ per year in the low IT producing sectors. US Department of Commerce, Digital Economy 2002, table $4.3 \mathrm{~b}$ and $4.3 \mathrm{c}$
} 
calendar scheduling (US Department of Commerce, A Nation Online, table 6-2, p 60). ${ }^{5}$ While lower paid and less educated workers are less likely to use computers at work, the spread of computers and Internet usage has been so wide that over half of persons in families with incomes below $\$ 15,000$ and over half of those with less than a high school education in the US report that someone in their household who uses "the Internet at work" (US Department of Commerce, A Nation Online, table 6.4., p 63). Scandinavia aside, adoption of IT has been slower in the UK and most of the EU than in the US, ${ }^{6}$ but the lags between the US and the other advanced economies are modest. The lead question is not whether working with computers and the Internet is becoming ubiquitous in advanced economies but whether using these technologies has substantial impacts on labour market outcomes and the way the job market and labour institutions function.

\section{Relation to hours worked}

One way to examine how the new technologies affect the labour market is to estimate the relationship between using the technologies and price and quantity outcomes. Studies beginning with Krueger (1993) have found that using a computer at work is associated with higher wages, though whether the relation is a causal one or is driven by unobserved heterogeneity whereby better workers use computers more and are paid more because they are better rather than because computerization raises their productivity remains debatable. ${ }^{7}$ The causal link from computer use to earnings rests on a disequilibrium analysis in which ITtechnologies shift demand toward persons who can best work with computers, creating at least a temporary premium for workers in that situation. ${ }^{8}$ Autor et al. (1998) provide a collage of evidence for this interpretation of the relation. Since demand shifts favourable to persons who work with computers should affect the quantity as well as price of their labor, working with a computer ought to be associated with greater hours worked as well as higher

\footnotetext{
${ }^{5}$ There are a substantial number of studies that have examined how computerization affects particular workplaces and the organization at work See Cappelli, 2000; Autor, Levy, and Murnane, 2000.

${ }^{6}$ The success of Scandinavian countries suggests that the US model, with its huge wage inequalities, does not offer the only road to success in the new economy.

${ }^{7}$ Using German data, DiNardo and Pischke (1997) found that using a pencil is also associated with higher wages, so that the observed correlation between computer use and wages could simply reflect higher level white collar work not otherwise captured in variables in standard data sets.

${ }^{8}$ When computer usage becomes virtually universal, regressions linking earnings to computer usage will become meaningless, but even so the pattern of coefficients over time will provide insight into how the spread of new technologies affects labour demand.
} 
hourly pay. Indeed, to the extent that computerization, particularly the Internet, allows workers to work at home more easily, the effect of the new technologies on hours worked could be more important over the long run than the effect of those technologies on wages.

To examine the link between the new technologies and hours worked, I have regressed natural logarithm of hours worked reported on the US's Current Population Survey (CPS) on dummy variables for computer usage at work and use of the Internet at work, conditional on a standard set of demographic and job-related covariates, as described in the data appendix. The data comes from the October Schooling and Computers supplements that previous studies have used to examine the link between computers at work and earnings and from previously unexamined Computer and Internet Use supplements for December 1998, August 2000, and September 2001. Using these data, I run three regressions - one linking hours to computer use (and covariates), one linking hours to Internet use (and covariates), and one linking hours to both computer use and Internet use (and covariates).

Table 2 summarizes the regression analysis in terms of the estimated coefficients on the computer or Internet variables and their standard errors. The regressions in column 1 give the coefficients for the effect of computer use on hours worked, with covariates in the regression but with no control for Internet use in the surveys that include an Internet question. The estimates show that computer use at work is associated with approximately 5\%-6\% higher hours worked, save for 1989 when the relation is modestly smaller. The regressions in column 2 link hours worked to use of the Internet at work. They show that accessing the Internet at work was associated with 5\% higher hours worked. Finally, column 3 gives the results for regressions in which both computer use and the Internet are entered together as explanatory variables. Since only the 1997 and 2001 surveys asked questions about both technologies, this column is limited to those years. Both computer use and Internet use are associated with additional hours worked, in the range of $4 \%$ in 2001, but with higher effects in 1997.

Since the hours questions on the CPS are about hours worked in the traditional workplace location, however, this measure is unlikely to capture the potential full impact of the new technologies on actual time worked. On the one side, absent any prompt to count time worked at home, most workers presumably limit their responses to time spent at the work place, rather than adding time for checking email, sending business messages, or working at their computer at night or on weekends at home. Specific questions about time 
worked at home or on vacation or holidays would presumably raise hours worked for many white collar workers for whom the new technologies blur work and home time. On the other side, access to the Internet at work creates opportunities for workers to sit at their desk and surf for personal non-work reasons. Indeed, the term "cyber-slacker" developed in the late 1990s to refer to workers who surfed the Web for personal reasons. An Angus Reid Survey ${ }^{9}$ estimated that $78 \%$ of Canadians with Internet access at work in 2000 used the Internet for personal reasons, averaging 2 hours a week, so that personal use accounted for $26 \%$ of surfing time at work In a 2001 UK survey $44 \%$ of workers with Internet access at work admitted to accessing non-related sites at work for over 3 hours per week in $2001 .^{10}$ Estimates of the proportion of workers who surf Web sites not related to work in the US varies widely, from $41 \%$ (Angus-Reid) to $46 \%$ ( "web@work" survey) ${ }^{11}$ to 90\% http://www.vault.com, ${ }^{12}$ depending on the particular question and population surveyed. The web@work survey estimated that workers spend over 2 hours per week surfing for personal reasons. Nielsen//NetRatings estimates that US internet users spend over twice as much time online at the office than at home, visiting finance, news, and electronics pages ${ }^{13}$. Many sites, including adult content sites, report getting their maximum hits during working hours as workers use fast access to the Internet at work to maximum advantage.

Surveys of human resource managers show considerable concern over the misuse of the Web. In a 2002 survey of 544 US companies $72 \%$ reported some form of Internet misuse by employees, and 1 in 4 said they had dismissed workers for Internet misconduct, generally for looking at pornography during the workday (Websense, Internet Misuse Survey 2002, July 2002). The human resource managers in this survey stated that workers should have 20 minutes a day for personal surfing, while they believed workers were spending about 30 minutes a day. One result of employer concern has been the development of employee Internet management software, which monitors employee use of the Web. The Privacy Foundation estimated that employers continuously monitored the Internet or e-mail use of one-third of the online workforce in 2001 (Schulman, July 2001). The critical question of whether the non-work related surfing time comes out of traditional work time or out of coffee break or lunch time or occurs before or after working hours, however, has not been

\footnotetext{
${ }^{9}$ Downloadable from www.websense.com/company/news/features /00/070400.pdf

${ }^{10}$ http://news.bbc.co.uk/ 1/sci/tech/1284823.stm).

${ }_{11}$ (www.websense.com/products/resources/wp/webatwork.pdf)

12 www.vault.com/surveys/internetuse2000/ results2000),
} 
investigated. It is plausible that personal use of the Internet at the workplace simply substitutes for other forms of leisure on the job rather than adding to that "downtime", or that it is related to the $5 \%$ increase in reported hours by workers with Internet access.

As work becomes more intellectual - weightless in Danny Quah's lingo (Quah, 2000b) - however, the sharp division between work time, non-work related web surfing, and leisure or home time itself becomes less meaningful. Perhaps casual discussion with friends or colleagues, or perusal of a newspaper or magazine or looking at some seemingly unrelated web site will provide the key insight or piece of information that makes for a successful work project. Just as mathematicians may make important breakthroughs thinking about some abstract problem on holidays rather than at their desk or blackboard, or as writers or artists get inspirations from coffee house chatter, so too may other knowledge workers perform their jobs in their heads outside traditional work venues. The worker who takes his or her problem home with them on a work break may be more effective than the worker who follows the 9 to 5 schedule. While detailed time budget data about time actually worked at a workplace and time worked at home would help us understand the impact of the Internet on work time, it cannot fully measure the "true" labour input into ideas, which can be produced in different locales under different conditions than can physical products.

\section{Relation to wages}

Table 3 examines the widely studied link between computer use and natural logarithm of hourly earnings. It updates previous analyses and estimates the link between the use of the Internet at work and pay as well as the link between computers at work and pay. Column 1 shows a sizeable premium of 0.15 to $0.16 \mathrm{log}$ points for working with computers through 2001, with no evidence that the premium falls over time. The stability of the relationship between computer use and earnings in the face of a rising proportion of the population using computers argues against any selectivity or sorting explanation of the correlation, since that pattern should be associated with falling differentials. The estimates in column 2 show that working with the Internet also had a substantial wage premium. Finally, column 3 shows that the impact of the Internet seems to have become greater than that of computer usage in general in 2001, with a coefficient twice as large as that for computer use.

\footnotetext{
${ }^{13}$ Reuters, “Work Surfing Dominates US Internet Use” April 6, 2000
} 
Working with a computer or using the Internet at work could affect the dispersion of pay as well as levels of pay. There are two competing ways in which use of computers and the Internet might affect the dispersion. On the one side, computerization standardizes some work activities, which should reduce dispersion. With a PC and common program, it isn't what you or I do but what the program does that determines our productivity and thus influences our wage. On the other side, however, computerization and the Internet could magnify differences in productivity. A small productivity differential can be magnified by the ability of the computer to replicate outputs at low marginal cost, with consequences for pay. To see whether there is any clear relation between use of computers or the Internet at work and the dispersion of pay, I have calculated the standard deviations of the natural log of hourly earnings for workers who work with these technologies and for those who do not. In 2001, I estimate that the standard deviation of log earnings for workers who use computers at work was 0.564 compared to 0.534 for workers who do not use computers at work. Similarly, I estimate that the standard deviation of log earnings for workers who use the Internet at work was 0.558 compared to 0.530 for workers who do not use the Internet at work. In earlier years, however, the inequalities were greater for workers who did not use computers or the Internet. These calculations suggest that the two effects are either too weak to have much impact on dispersion or are essentially offsetting.

\section{Death of distance and the job?}

Two outstanding claims about the impact of computers and the Internet on work appear to be vast exaggerations, at least at this time.

The first is the "death of distance" claim that the Internet eliminates the importance of location on work activities, weakening the economic rationale for cities, in particular. The Progressive Policy Institute has stated this claim sharply "As an increasing share of economic inputs and outputs are in the form of electronic bits, the old locational factors diminish in importance"(Progressive Policy Institute, 2002, p 4). Perhaps the best example of the reduced importance of locality is teleworking - the process of working at home at least one day a week while maintaining contact with one's office through computer technology. In the US an estimated 25 million workers telework. In the EU an estimated 9.1 million workers 
telework. $^{14}$ But the possibility for interacting digitally rather than face to face has not produced a dispersal of new economy jobs. To the contrary, traditional agglomeration economies operate in IT sectors as much or more than elsewhere, producing geographic clusters of IT, of which Silicon Valley and Boston's Route 128 are the most prominent examples. One presumed reason for this is that much important information, be it business or scientific or technological, is tacit, requiring human interaction to be effectively transmitted.

Table 4 examines the variation in the extent of the new economy among US states, using the Progressive Policy Institute's New Economy data on 21 different new economy indicators (such as online population, IT employment, R\&D, venture capital, etc). It also records data on union density, the rate of taxation, and educational spending. For ease of presentation, the table summarizes the data in terms of the value of the relevant variables for the ten states rated highest in the PPI's New Economy aggregate Score, based on all 21 indicators and for the ten states lowest in the New Economy Scores. The states that score highest in the new economy score are located along the US coasts (Colorado aside) while those that score lowest are Southern and Mountain states that often receive high business climate scores for having low wages, low taxes, and low unionisation.

Column 1 gives the New Economy Index score for each state - a weighted average that the PPI has used to best capture what is new about the New Economy (PPI, 2002, Appendix A). Columns 2 and 3 show that the top states have much higher percentages of employment in IT professional jobs and in high-tech industries than the bottom states. By contrast, column 4 shows that the top states do not differ much in the percentage of the population that is online relative to the bottom states. The IT jobs are geographically concentrated; even though Internet access is diffused widely. The implication is that location matters in where the New Economy jobs are whereas access to the Internet is not critical. In addition, although the PPI counts job churning as a sign of the new economy, column 5 shows that the top ten states differ little in the extent of job churning from the bottom ten states, indicating that job insecurity or fluctuations are not in fact characteristic of the new economy.

This does not mean that the Internet has no effects on the location of business activities or employment. Quah (2000a) has suggested that the "weightless economy" could

\footnotetext{
${ }^{14}$ The US data are reported in Wall Street Journal, March 28, 2002 "Empty Cubicles"; the EU data are from The Institute of Employment as reported in (http://www.nua.ie/surveys/index.cgi? f=VS\&art_id=905358148\&rel=true)
} 
produce more subtle changes in the coordination and timing of business activity than the death of distance: waves of business activity across different time zones. Consider the efficiency advantage of dividing a work project so that people in one time zone begin the project, then pass the product to people in another zone, who do the same. If people work on an 8 hour day, this would link workers in time zones differing by just 8 hours, creating a 24 hour 3 shift work day for the product. The development of Bangalore as a programming work site linked largely to the US could be due to this time zone effect.

The second claim about new economy jobs is that they produce employee/employer relations that diverge greatly from the traditional long term permanent jobs that have characterized capitalist economies. In the mid 1990s Fortune heralded "the end of the job" and various commentators have since argued that new economy jobs are disproportionately short term contract work, rather than full-time employment. The idea is that in the new economy, people work on projects rather than for employers. This is the pattern of production in Hollywood, where a producer puts together a team to make a movie, then dissolves the team when the production is over, so that movie personnel move from temporary contract to temporary contract.

Some New Economy IT work follows this pattern. There is an active market in "ework", where market intermediaries bring together IT or other specialists with firms for contract work, providing a market venue in which to conduct the operation and reputation capital to assure that neither the worker nor firm is ripped off. One large operation is www.eworks.com, which as of summer 2002 had listed some 14.6 billion dollars of contracting work for some 332,736 users, who made 102,791 transactions. In another part of its Internet business, it managed the full transactions for contract workers, processing time sheets, paychecks, vendor invoices, and consolidated client invoices. In this type of market firms and workers usually report afterwards on the success of the match so that they develop reputations for future work arrangements.

But the replacement of permanent work with contracting out in the New Economy appears to be vastly exaggerated. Studies of job tenure, which should decline massively if permanent employment were a pattern of the past, show some limited fall in tenure for men but increased tenure for women (Farber, 1995). Neumark and Reed (2002) have found that high-tech industries make no greater use of contingent workers or alternative employment relationships than other industries. Indeed, it is construction and personnel supply services, 
which are hardly new economy sectors, which make greatest use of contingent or alternative workers. Rather than building their business Hollywood style, the dot.coms that proliferated in the late 1990s operated under a traditional committed worker relation, giving stock options and shares to employees to attract them.

\section{Job Search and Recruitment in Cyberspace}

Job search and recruitment are major activities on the Internet. Each week millions of workers around the world search job boards or corporate sites for vacancies, and many apply for jobs on-line as well. In addition, millions of workers post their resumes or CVs at recruitment web sites in the hope of attracting job offers. For their part, nearly all large firms advertise jobs on their web sites and/or list jobs with internet recruitment firms. As a result of the shift of search and recruitment to the Web, Internet recruitment firms have been one of the successes of the dot.com world. In 2000 three of Price Waterhouse Cooper's 15 most successful non-listed businesses in the UK were intern recruitment firms, including the top ranked Jobserve. In the US, two of the dot.coms with sufficient resources to buy advertisements for the 2001 Super Bowl were Internet recruitment giants, Hotjobs.com and Monster.com.

Table 5 presents data on the use of Internet for job search by workers from the US and UK. The bulk of the US data are from the Current Population Survey, which asks workers if they use the Internet regularly for job search, and the Nation On-line survey of the Department of Commerce. The UK data are from www.workthing.com 's 2000 Online Recruitment and Employment survey; and from the April 2002 National Online Recruitment Audience Survey (NORAS) conducted among unique visitors to 6 generic Internet job sites and 2 sector specific sites. Panel A shows that these surveys report that a substantial proportion of online persons use the Web for job search, making it one of the most common usages of the Web. Sixteen percent of online Americans report searching for a job on the Web in 2001 with younger workers making up a disproportionate share of those online job searchers. Half of unemployed Americans with home access to the Web used it for job search and $15 \%$ of the employed with home access used it for job search. Even though many 
persons still do not have home access in the US, upwards of $8 \%$ of the entire labor force reported looking for jobs on the Web.

The Online Recruitment and Employment survey asked workers about search over the past six months. Nearly a third of the online adults reported using the web for job search over that period. More striking, of the online British workers who said that they were looking for a new job, 75\% said that they searched the web. In April 2002, when the NORAS survey was conducted, one large and popular generic job site in the UK, Fish4jobs, had over 700,000 unique visitors. Because of the relative ease of searching for jobs on the Web, a substantial number of employed persons use the medium for job search in the UK and in the US. The NORAS survey estimates that $22 \%$ of searchers were unemployed whereas $54 \%$ had full time jobs and another $18 \%$ had some other employment status. The typical job seeker went to an average of 4.7 sites as part of their search process. As in the US, a disproportionate share of persons using the Web for job seeking in the UK were younger workers

Panel B of table 5 shows the flip side of the market: the widespread use of the Internet by firms to post vacancies and recruit labour. Virtually all major firms in the US and UK list job vacancies on the Web and the vast majority allow applicants to apply on-line. In 2002 $71 \%$ of firms at a UK seminar on the impact of technology on Human Resources reported advertising on Internet job boards, though the majority said that they found that their corporate website was the best source of quality candidates (Enhance Media, 2002).

With so many workers and firms using the Internet for job search and recruitment, it is not surprising that the distribution of skills and jobs goes far beyond IT occupations or industries, where Internet recruitment began. Panel C documents this for the UK in 2002. Just $10 \%$ of Internet job seekers reported looking for IT jobs and just $10 \%$ said that they were currently employed in IT industries. One has only to surf the large job boards to realize that while most of the vacancies on offer are white collar and skilled, firms post jobs for virtually every type of work. This said, IT and New Economy sectors or areas of the economy do make more extensive of the Web as a venue for matching workers and firms than other areas. In the UK job search on the Web is more common in the Southeast than in the older industrial North (NORAS, 2002). In the US the number of job vacancies listed on Mons ter.com varied across states in 2000 according to the state ranking on the concordant New Economy index. For example, Massachusetts and California, which rate high in the New Economy index had many more job vacancies listed per worker on the so-called Monsterboard than Mississippi or 
West Virginia. Formally, I document this relation by regressing the number Monster's job vacancies per employed person for each of the 50 states on total employment in the state and on the state's new economy score (NES) ${ }^{15}$ using a log-log functional forma and obtained the following result:

(1) $\log$ Monster Vacancies/Employment $=-9.28+0.28 \log$ Employment $+1.91 \log$ NES

where the numbers in parenthesis below the estimated coefficients are standard errors and where the $\mathrm{R}^{2}$ was 0.95 . If the cross section relation between the new economy and use of the Internet for recruitment holds over time, Internet recruitment will continue to grow very rapidly - at nearly twice the rate of the growth of the New Economy.

The reason for the rapid movement of job search and recruitment to the Web is simple: workers seeing jobs want information about the jobs on offer; while employers seeking workers want information about persons seeking work; and the Internet is the lowest cost way to transmit information throughout the economy. Firms can post advertisements for jobs on the Web for roughly a tenth the price of buying a want-ad in newspaper classifieds and obtain rapid responses through on-line applications. Workers can search for a wide variety of jobs and apply relatively easily for those jobs without leaving their home (or perhaps their office) and can be notified by e-mail that particular firms are interested in them. They also can obtain diverse information about prospective employers from the Web.

\section{How Internet recruitment works}

Internet recruitment sites differ widely in their form and in the services they provide. Most sites are "job boards" - the electronic equivalent of newspaper vacancy ads - that list available jobs grouped by occupation, location, and so on (panel B Table 5 gives an estimate of the number of job boards) These sites sell firms or recruitment agencies the right to post job details. The traditional sources of vacancy ads, newspapers and specialized magazines, have responded by offering free web listing for their own job advertisers and have developed

\footnotetext{
${ }^{15}$ In these calculations I use the New Economy Score for 1999 rather than for 2002, as in table 4. There are some modest differences in the position of states between the two years.
} 
their own web-based recruitment sites. By contrast, $\mathrm{CV}$ database sites specialize in gathering $\mathrm{CV}$ s from workers and charge firms for accessing their $\mathrm{CV}$ database (panel $\mathrm{B}$, table 5 gives estimated numbers, as well). Some of these firms charge firms only when the firm finds candidates it seeks to pursue. Others earn commissions on actual placements. Many sites offer both job boards and CV databases. All Internet recruitment sites earn revenue from firms while providing services freely to workers. For workers the direct cost are largely the time costs of search., though they may bear some of the incidence of the firm's costs of search.

The development of Internet recruitment sites highlights the advantages of network economies or scale economies in job search and recruitment. Persons seeking work want sites with many jobs on offer and few competing applicants. Firms seeking employees will prefer sites with many job seekers but few competing vacancy ads. There is thus an inherent advantage to sites to gain popularity on both sides of the market. Presumably, there is also an equilibrium level of vacancies per job applicant, with sites having many vacancies per applicant drawing more applicants and fewer vacancies over time; and sites having few vacancies per applicant, gaining vacancies and losing applicants. To attract workers to search on their site and post their CVs, many Internet recruitment sites offer free information about salaries or training opportunities, and give advice about best ways to interview for a job along with other career and job-seeking advice.

Network and other forms of scale economies suggest that a few large sites may ultimately dominate Internet recruitment. One countervailing factor, however, appears to be the advantages of small specialized niche sites, which link employers and workers in specific industries, occupations, and sectors. Rather than searching a mass site for jobs, computer specialists can choose among several IT-specialized sites, bankers can search for jobs on specialized banking job sites, while academics focus on sites that deal with university jobs,

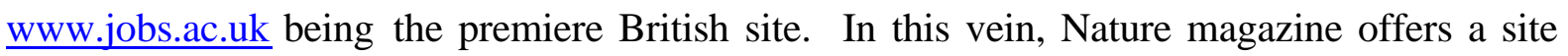
for science jobs. Many scientific specialties offer sites for persons in their discipline.

Finally, the industrial structure of the Internet recruitment business varies greatly across countries. In the US and UK private sector firms dominate Internet recruitment. The US market is relatively concentrated with Monster.com and Hotjobs.com being particularly important. In the UK, there are several sites that attract many job seekers and that host many vacancy listings, making the industry less concentrated. In Sweden, by contrast, the 
dominant recruitment agency is the public sector employment service. In Germany and France also the public sector employment service plays a major role in Internet recruitment, with the German employment service listing the resumes of all its jobless persons on the Internet.

\section{Labour market outcomes}

Internet job search and recruitment offers three potential efficiency gains to the economy: reduced transactions costs; speedier clearing of the job market; and better matching between workers and vacancies.

The lower transactions cost of the Web can be documented easily for firms. Estimates by Alan Krueger (personal communication) show that in 2000 the 8 hrgest job boards in the US drew some 1.8 million unique visitors and charged an average $\$ 98$ for placing a vacancy. By contrast, 8 major newspapers, with Sunday circulation of 1.0 million readers, charged $\$ 3,840$ for placing an advertisement for 30 days. Monster.com, which had 3.9 million unique visitors in 2000 , charged $\$ 138$ compared to $\$ 4,500$ for the NY Times, with 1.7 million Sunday readers. The Employment Management Association estimates that a hire obtained by the Internet costs a firm one-fifth as much as a hire obtained using print media.

Peter Kuhn (2001) has examined the success with which workers who use the Internet find jobs in the US compared to the success with which workers using other forms of job search find jobs. His results, based on following unemployed persons longitudinally on the US Current Population Survey show no discernible difference. This may reflect the already low rate of frictional unemployment in the US, where the unemployed find jobs sufficiently rapidly as to leave little margin for an increased rate of job-finding. In the EU where unemployment spells are long, Internet job search might improve the rate of job finding and bring the economy closer to full employment. It may reflect limitations of the CPS Internet job search question, which simply asked if the person generally used the Internet for search However, the absence of any relation between Internet job search and time to find work may also reflect the fact that the reduced search costs is likely to increase the amount of search, both by the unemployed and by employed worker, slowing the process of filling vacancies. In a standard search model, after all, the cost of search influences the time searched, so that if the Internet is more effective in matching employees with jobs, the improvement will 
increase time searched by making it cheaper to find a good match The impact of the Internet on total time searching for jobs will depend on the magnitude of this price effect on time searched compared to the reduction in time searched due to the technological improvement in search. Which effect will dominate is an empirical matter. For their part, firms that use the Web to recruit often complain about the problem of evaluating an inordinate number of applicants. In $200259 \%$ of firms in a UK survey reported that integrating back end technology was the "biggest issue facing online recruitment in the UK", by which they mean having sophisticated computer programs to assess online applications (Enhance Media, 2002).

Internet recruitment has the potential for making its biggest contribution to the labour market by producing better job matches. By diffusing information about jobs widely, the Internet should help break down old boys networks and traditional geographic barriers. Someone sitting in an Internet café in a small village in Portugal, for example, can peruse jobs in London or Paris and apply. If they have the skills, they will be able to beat out a less qualified candidate from the local area. Here too, however, the critical bottleneck appears to be the back end technology for matching worker qualifications with job requirements. Better matching could, however, have one potentially adverse effect on the job market. As Autor (2001) notes, it could widen inequality by making clearer which workers are best suited for given jobs and raising competition for their services. There is as yet no empirical analysis on this issue.

\section{Union Use of the Internet}

"The membership of trade unions will increasingly demand the levels of services which can only be provided by the ... e-union ... Our members will find that in dealing with other organisations they are given increasingly speedy and personalised service on a 24hour 7-day-a-week basis. They will expect no less from their trade union" (Roger Darlington, Communication Workers Union, UK)

Although unions have been slower than commercial firms to adapt to the Web, all national unions and most large local unions are now on-line in the US and UK (Diamond and 
Freeman, 2002) and use the Web and other IT technologies as part of their normal operations (Delaney, et al, 2000; Greer, 2001). In the UK the public sector union UNISON established the first union website in the UK in March 1995, but by April 2001, there were over 300 union web sites in the UK. For the entire world, Diamond and I (2002) estimate that there over 2700 union web sites, with the majority in the English-speaking world. In these countries and in Scandinavia, leading edge unions and activists increasingly see the Web as an important avenue for modernising and advancing unionism and bridging the gap between an increasingly heterogenous work force and collective activity and solidarity. All of the major international union federations make extensive use of the Internet in delivering information and services to unions and activists around the world. The question is not whether unions are adopting to the Internet and IT but whether or not they can use the new technologies creatively to modernise their modes of operation and rejuvenate themselves in the New Economy.

\section{The five hypotheses}

A variety of analysts have debated and speculated about the opportunities that the Internet and IT offer to unions and about their potential response to these opportunities (Shostak 1999). I encapsulate these arguments and speculations into five hypotheses regarding the impact of IT on unions and examined cases that show how innovative unions are in fact operating in each area. I refer to the five statements as hypotheses because at this writing it is not possible to tell whether a sufficient proportion of unions will successfully use the Web in any of the posited ways to justify the claim that this is the predominant union response to the IT technologies.

1. The customised service hypothesis, which the Darlington quote above represents, holds that unions can use IT and the Web to access information about members that will allow them to give personal service that would otherwise be prohibitively expensive and can also use the Web to provide generic information about worker rights through FAQ's and diverse forms of information. The best examples of these two activities are two UNISON initiatives in the UK. The first is the www.troubleatwork.org.uk site which UNISON formed in conjunction with the National Union of Students to provide information and advice on work-related problems for student workers on the Internet. The topics covered range from 
health and safety issues to contracts to holidays, time out breaks, discrimination, lifting heavy objects, temping, to joining a union. The second is UNISON-Direct, which offers members who have problems at a workplace the right to call a help line 24 hours a day to receive information and advice from persons who have over 300 computerized scripts to guide them in dealing with problems. (Whitfield, 2002) Another initiative is the TUC's Risks email alert system, which gives weekly health and safety updates to union representatives and activists.

2. The new internationalism hypothesis holds that the Internet can increase worker and activist solidarity, creating a new internationalism by linking unions and sympathisers around the world with instant labour news and modes of communicating (Lee, 1996). The most important site for the new internationalism is www.labourstart.org, which gives daily labor news from newspapers around the world, and is linked to several hundred union web sites around the world. The site operates at low cost because volunteer correspondents post the news from their area. If the Korean government orders police or soldiers to attack strikers in Busan, the story will make labourstart, whereas it may be hard to find in a regular newspaper in Europe or the US. Going beyond provision of news, LaborNet (US,

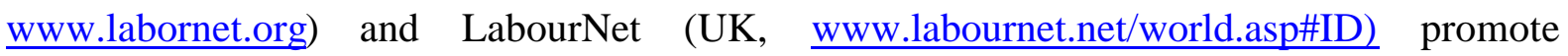
computer communications for strengthening and building organised labour. LabourNet states that because "International co-operation and solidarity has become totally essential." for unions to do their job. "... we are working towards the widest possible international labour network ... the fullest possible discussion on the issues facing our movement within LabourNet conferences, lists and our web sites for coming labour movement events, etc. from around the world. Our emphasis is on contributions and reports from rank and file trade unionists...."

3. The cyber dispute hypothesis holds that unions can use the Internet to present their case to members, business, and the general public without going through standard media channels and can pressure firms to acquiesce to union demands through Web-based actions. In the 2001 Communication Workers (US) strike against Verizon, the union posted daily bargaining updates on its web site, with access restricted to members. Other unions have used the Internet to organize wider protests to help workers in disputes in particular localities. One example is the 2000 Steelworkers strike in North Carolina against German-owned Continental General Tire. The union provided information to activists around the US via Internet posting that led the activists to pressure tire distributors and purchasers of 
Continental products including Walmart and Ford. Some 80-100 Internet postcards were sent to the headquarters in Germany. Changing the locus of the dispute from one of the least union friendly states in the US to the wider world helped the union win its dispute. In the 2000 strike by the Society of Professional Engineering Employees at Boeing, one of the largest white collar strikes in US history, the union used its web page to keep members alert to the latest twists and turns of the negotiations. Finally, the Hotel and Restaurant Employees Union site www.eyesonsodexho.com provides data on Sodexho-Marriot's record in food safety and labor relations that makes it hard for the public to sympathize with the firm in any organizing drive.

4. The cyber-organizing hypothesis holds that unions will organize workers on-line and develop virtual presences even at companies where the union lacks sufficient membership to gain recognition. One example of organizing over the Web is the United Food and Commercial Workers' site, www.walmartworkerslv.com, which the UFCW describes as follows: "Although we do print publications as well, we've found most of our members use the Internet and enjoy this medium. They have learned about the process and keep up-to-date on current Wal-Mart activities online. It's also a vehicle for the community to see how our campaign is running and what we're really up against so that War-Mart Corporate is not the only one talking." The National Writers Union, which is part of the United Automobile Workers, reports that $1 / 3$ rd to $1 / 2$ of its new members join via the Web. This union has no collective bargaining contract and operates almost exclusively on the Internet, describing its web site as its union hall (Hartford, 2001). Yet another example is the Communication Workers of America (CWA) local union at IBM, www.allianceibm.org, which has voting members (75\% of whom sign up on line) who pay union dues and "subscribers" - workers who use the site to learn about company actions and union plans. This union is able to survive even though the probability of getting a collective agreement from IBM in the US is minimal because the Web offers it a low cost way to connect with IBM workers and the general public (Guyer, 2001).

5. The union democracy hypothesis holds that the $\mathrm{Web}$ will create greater opportunity for union democracy by allowing rank-and-file members to participate more fully in decisions and by giving dissidents greater ability to make their case against incumbent leadership. Some unions have established members only chat rooms and forums, and some have organized Internet voting over particular issues, but most prefer to use the Internet to 
communicate to workers rather than to involve them in decision-making. The impetus for change comes more from dissident groups within unions, who can bypass the union hierarchy's control of the internal media, to send their message to members; and young activists, who simply want to get on with their union business without being hassled by oldfashioned officials.

\section{How far can unions take IT and the Internet?}

The examples above show that the pieces for a very different New Economy union movement can be found in different places. If unions adopt many of the innovations summarized here, within a decade or so, unions in advanced countries will be very different organisations than in the past (Freeman and Rogers, 2002).. Some new economy union services will make unions more like professional associations or guilds. Some will make them more like personal agents for their members. Some will change the very meaning of union membership. But it is by no means clear that union leaders will in fact move aggressively on this front. For a variety of reasons, unions may fail to transform their organizations or may lose some of their functions to other types of organisations that use the Web to offer workers information and advice, Internet recruitment sites, law firms, non-profit community groups, government agencies, and firms themselves, offer free information and advice to workers. There are also potential legal problems in workers using the Internet at their workplace to contact unions. Most important, there are organizational problems in moving large political organizations, usually run by the pre-Internet generation, to pursue the opportunities that the Internet offers.

Indicative of the gap between the leading examples and the regular operation of unions on the Internet, the 2001 British Workplace Representation and Participation Survey asked union members about their unions' web site. (Diamond and Freeman, 2001) Barely $20 \%$ of union members said that they had accessed their unions' web site and many of those gave it a low rating for providing useful information to them. Still, the pressure on unions to survive and be relevant is a powerful one, and if exploiting IT and the Internet can help, I would expect to see the right mix of services and activities on the Web to grow. 


\section{Conclusion}

In the 1990s most discussion of the Internet and IT focused on the dot.coms and e-commerce, with little attention given to the fact that the Internet and IT technologies were changing the labour market and labour organisations. The evidence given in this paper shows that there were in fact important changes in the labour area - changes in the demand for labour; in hours worked; in hourly pay; in the mechanisms by which the market brings supply and demand into balance; and in the way unions operate. One does not have to be a technological determinist or new economy enthusiast to appreciate that the IT and Internet-induced changes in the labour market have been substantial and that these changes are likely to increase as computerization and Internet access increase over time. I expect that in the foreseeable future more labour market transactions - job search, recruitment, and matching - will occur over the Web and that union members and nonmembers alike will look to the Web as their way of learning how to address workplace problems. As much as any other market, the labour market will expand in cyber-space. 
Table 1: Employment in IT Sectors and Computer and Internet Use at Work in the US, 1980s-2000

1 Share of Employment in IT producing Industries

1992

2000

4.3

2 Share of Employment in IT Occupations

1992

4.0

2000

5.1

3.Rates of Growth of Employment in IT-using industries, 1989-2000

Top half, by investment per worker $\quad 1.8 \%$ per year

Bottom Half, by investment per worker $\quad 2.2 \%$ per year

4. Share of Employed Using Computers at work

1984

24.6

1989

37.4

1993

46.5

1997

51.1

2001

55.9

5. Share of Employed Using Internet at work

1997

17.3

1998

19.7

2000

24.6

2001

40.5

Source:

1 - 1992 Department of Commerce, Digital Economy 2002, reports 3.6 million IT industry workers in 1992 and 5.6 million in 2000, p 42

2 - 2000, from Department of Commerce, Digital Economy 2002, p 44 reports 6.7 million 1992, Digital Economy 2000, p 46, reports 4.3 million in 1992 and 5.3 million in 1998. There are some changes in definitions between the years, so this is approximate at best.

3 - US Department of Commerce, Economics and Statistics Administration, Digital Economy 2002, Appendix , table A-4.2b, A -4.2c

4 and 5 - Tabulated from Current Population Survey, School Enrollment and Computer supplements, October; Computer and Internet Use supplements, Dec 1998; August 2000; September 2001. 
Table 2: Regression Coefficients (standard errors) for the Impact of Working with Computers and the Internet on Log Hours Worked

\begin{tabular}{|l|l|l|l|}
\hline regression & (1) & (2) & (3) \\
\hline
\end{tabular}

\begin{tabular}{|l|l|l|l|l|}
\hline $\begin{array}{l}\text { independent } \\
\text { variable }\end{array}$ & computer & Internet & computer & Internet \\
\hline 1989 & $\begin{array}{l}.031 \\
(.005)\end{array}$ & ---- & ---- & ---- \\
\hline 1993 & $\begin{array}{l}.050 \\
(.006)\end{array}$ & --- & ---- & --- \\
\hline 1997 & $\begin{array}{l}.073 \\
(.006)\end{array}$ & $\begin{array}{l}.037 \\
(.007)\end{array}$ & $\begin{array}{l}.070 \\
(.007)\end{array}$ & $\begin{array}{l}.013 \\
(.008)\end{array}$ \\
\hline 1998 & --- & $\begin{array}{l}.052 \\
(.006)\end{array}$ & -- & --- \\
\hline 2000 & ---- & $\begin{array}{l}.048 \\
(.006)\end{array}$ & --- & -- \\
\hline & $\begin{array}{l}059 \\
(.006)\end{array}$ & $\begin{array}{l}.035 \\
(.007)\end{array}$ & $\begin{array}{l}037 \\
(.007)\end{array}$ \\
\hline
\end{tabular}

Source: Tabulated from CPS files, as described in the data appendix, with all regressions including the set of covariates as given in the Appendix.

Regressions 1 and 2 enter computer use and Internet use separately

Regression 3 enters the computer use and Internet use together. Since only in the 1997 and 2001 surveys are questions asked about both technologies, this equation is estimated only in those years. 
Table 3: Regression Coefficients (standard errors) for the Impact of Working with Computers and the Internet on Log Hourly Earnings

\begin{tabular}{|c|c|c|c|c|}
\hline & \multirow{2}{*}{$\begin{array}{l}(1) \\
\text { computer }\end{array}$} & \multirow{2}{*}{$\begin{array}{l}(2) \\
\text { Internet }\end{array}$} & \multicolumn{2}{|c|}{ (3) } \\
\hline & & & computer & Internet \\
\hline $1984 *$ & $\begin{array}{l}.17 \\
(.008)\end{array}$ & --- & - & ---- \\
\hline 1989 & $\begin{array}{l}.151 \\
(.008)\end{array}$ & - & - & --- \\
\hline 1993 & $\begin{array}{l}.164 \\
(.009)\end{array}$ & - & ---- & ---- \\
\hline 1997 & $\begin{array}{l}.155 \\
(.010)\end{array}$ & $\begin{array}{l}.142 \\
(.012)\end{array}$ & $\begin{array}{l}.129 \\
(.010)\end{array}$ & $\begin{array}{l}.097 \\
(.012)\end{array}$ \\
\hline 1998 & ---- & $\begin{array}{l}.127 \\
(.011)\end{array}$ & & \\
\hline 2000 & ---- & $\begin{array}{l}.141 \\
(.010)\end{array}$ & & \\
\hline 2001 & $\begin{array}{l}.145 \\
(.009)\end{array}$ & $\begin{array}{l}.174 \\
(.009)\end{array}$ & $\begin{array}{l}.060 \\
(.012)\end{array}$ & $\begin{array}{l}.137 \\
(.012)\end{array}$ \\
\hline
\end{tabular}

Source: Tabulated from CPS files, as described in the data appendix, with all regressions including the set of covariates as given in the Appendix.

* From Krueger (1993) 
Table 4: Characteristics of US States by their "New Economy" Score, 2002

\begin{tabular}{|c|c|c|c|c|c|c|c|c|}
\hline & New & Conol & y Mea & ures & & Institution & al/Social W & Ifare \\
\hline $\mathrm{Neu}$ & $N$ Econ & $\%$ IT & $\% \mathrm{Hig}$ & $\%$ & Job & \% Union & State \& Loc & 1 Educ \\
\hline Score & Profs & tech & On-lir & e Chu & & $\mathrm{Tax} / \mathrm{In}$ & icome Sper & ding \\
\hline Top 10 States & 78.3 & 23.6 & 7.2 & 58.0 & 20.0 & 15.4 & 10.2 & $\$ 7738$ \\
\hline Mass & 90.0 & 2.5 & 10.4 & 56.7 & 17.4 & 14.3 & 9.5 & 7861 \\
\hline Washington & 86.2 & 2.8 & 6.6 & 61.3 & 21.3 & 18.2 & 10.5 & 6488 \\
\hline Calif & 85.5 & 2.2 & 8.9 & 52.1 & 21.3 & 16.0 & 10.3 & 5345 \\
\hline Colorado & 84.3 & 3.3 & 10.0 & 60.1 & 22.1 & 9.0 & 9.1 & 5704 \\
\hline Maryland & 75.6 & 2.4 & 6.6 & 61.4 & 19.8 & 14.6 & 9.7 & 7376 \\
\hline New Jersey & 75.1 & 1.9 & 7.1 & 60.0 & 19.7 & 20.8 & 10.3 & 10427 \\
\hline Connecticut & 74.2 & 2.2 & 6.6 & 58.6 & 17.8 & 16.3 & 10.9 & 9218 \\
\hline Virginia & 72.1 & 2.5 & 7.5 & 58.5 & 19.8 & 5.6 & 9.4 & 6569 \\
\hline Delaware & 70.5 & 2.1 & 3.4 & 58.4 & 20.5 & 13.3 & 10.2 & 8576 \\
\hline New York & 69.3 & 1.7 & 5.3 & 53.0 & 19.2 & 25.5 & 12.3 & 9812 \\
\hline Bottom 10 States & s $\mathbf{4 5 . 3}$ & 7.6 & 2.5 & 50.1 & 19.0 & 7.9 & 10.0 & $\$ 5566$ \\
\hline So Carolina & 51.1 & 0.9 & 2.5 & 47.7 & 20.4 & 4.0 & 10.0 & 5555 \\
\hline Kentucky & 48.6 & 0.9 & 2.5 & 53.2 & 18.8 & 12.0 & 10.5 & 6283 \\
\hline South Dakota & 47.4 & 1.2 & 4.7 & 58.8 & 17.8 & 5.5 & 9.1 & 5166 \\
\hline North Dakota & 46.1 & 0.3 & 2.6 & 56.5 & 16.3 & 6.5 & 10.2 & 4978 \\
\hline Louisiana & 45.9 & 0.8 & 1.6 & 43.4 & 19.5 & 7.1 & 9.8 & 5194 \\
\hline Wyoming & 45.7 & 0.7 & 1.4 & 62.3 & 19.4 & 8.3 & 9.8 & 6312 \\
\hline Alabama & 45.3 & 0.9 & 3.3 & 46.2 & 20.1 & 9.6 & 9.1 & 5110 \\
\hline Arkansas & 41.7 & 0.5 & 2.4 & 44.3 & 20.8 & 5.8 & 10.2 & 5222 \\
\hline Mississippi & 40.9 & 0.6 & 1.9 & 41.8 & 19.7 & 6.0 & 10.7 & 4732 \\
\hline W. Virginia & 40.7 & 0.8 & 2.1 & 46.7 & 17.4 & 14.3 & 10.5 & 7110 \\
\hline
\end{tabular}

Source: New Economy measures, from Progressive Policy Institute, 2002 State New

Economy Index Indicators the Rankings, pp 8-9 http://www.neweconomyindex.org/states/,

New economy score is the weighted average summary reported by PPI

$\%$ IT professionals is the percentage of employed who are information technology professionals

$\%$ High tech is employment in electronics manufacturing, software and computer-related services, telecommunications, and biomedical as a share of total employment

$\%$ on-line is the percentage of the population in the state that is on-line

job churning is te number of new start-ups and business failures, combined, as a share of all establishments in each state.

\% Union, US Bureau of the Census, Statistical Abstract 2001, table 639

State and local Tax/Income, Tax Foundation, Effective State and Local Tax Burdens by State and Rank Calendar Year 2002 http://www.taxfoundation.org/statelocal02.html

Educ spending is average current expenditures per pupil in average daily attendance, from

US Bureau of the Census, Statistical Abstract 1999, table 286. 


\section{Table 5: The Internet as the New Venue for Job Search and Recruitment}

\section{A. Magnitudes of Job search}

$16 \%$ of online Americans 15+ searched for job online in 2001

$26 \%$ of those aged 25-34 searched for job online

$17 \%$ of those aged 35-44 searched for job online

$50 \%$ of US unemployed with home access $/ 15 \%$ of all unemployed regularly used web for job search

$15 \%$ of US employees with home access/ $7 \%$ of all employees regularly used web for job search

$18 \%$ of US labor force with home access/ $8 \%$ of labor force regularly used web for job search

$31 \%$ of online British searched for jobs on the web in past 6 months; (2000)

$75 \%$ of online Brits looking to change jobs searched on the web (2000)

\section{B. Magnitudes of Internet Recruitment}

All but one of top 20 Fortune 1000 firms advertise jobs on home-page; allow for online application

Hundreds of thousands of firms post job related information on Web

Estimated 2,500+ job boards with 9.4 million postings in 2000

Estimated $500 \mathrm{CV}$ clearing houses in 2000

\section{Wide Distribution of Occupations/Industries of Job Seekers/Jobs on Web}

Jobs Sought (2002): Administrative/Sec (13\%); IT (10\%); Engineering (7\%); Sales (6\%); Customer Service (6\%); Management (6\%); Others scattered (62\%)

Industry of job seeker (2002): IT (9\%), Mfg (7\%); Retail (6\%); Engineering (6\%); Banking/Finance (6\%); Others scattered (66\%)

\section{Estimates of Internet-initiated Matches}

$4 \%$ of online US jobseekers found most recent jobs over the Web

$39 \%$ (2000) to $60 \%$ (2002) of online British job seekers applied for job found on Web

$10 \%$ of online UK jobseekers interviewed as result of online application (2000) (2000)

$4 \%$ of online UK jobseekers found job through Internet online or offline application

Sources:

USA, data on percentage of unemployed who use Web Kuhn (2000); Data on percent who search for jobs, from US Department of Commerce (2002b), A Nation Online, figure 3.2, 3.3; UK, all numbers with 2000 date are taken from Workthing internet recruitment survey, 2000; all numbers with 2002 date are taken from NORAS survey. 


\section{Data Appendix}

Tables 1, 2 and 3 use data from supplements to the US Census Bureau's monthly Current Population Survey (CPS). The October 1989, and 1993 School Enrolment Supplements asked respondents about their computer use at home and at work, and the October 1997 supplement included additional questions about Internet use. In December 1998 and August 2001 the Computer and Internet Use Supplement asked respondents about Internet use at home and at work; questions relating to computer use at work were added to the September 2001 supplement.

The OLS regressions in Tables 2 and 3 include dummy variables for: marital status, gender, married*female interaction, non-white race, veteran status, part-time workers, selfemployed workers, union membership, SMSA status (a control for metropolitan residence), and three region dummies (the Midwest region was omitted). In the samples from 1993 onwards, there are seven dummy variables for education: less-than high school, high school diploma, some college experience, associate degree, college degree, masters degree, and doctoral degree (the omitted group iss holders of a professional qualification). The 1989 survey used a different educational attainment question, such that masters, doctoral, and professional degree holders were grouped into one. A measure of respondents' experience was calculated from their number of years of schooling, as estimated from educational attainment. Experience squared (and multiplied by 100) also enters the regressions. Finally, we used eleven occupation dummy variables: handlers/laborers, transportation, machine operators, craft/repair, other services, administrative support/clerical, sales, technical, professional, and managerial (the omitted group is farming/fishing/forestry). All regressions include an intercept.

The dependent variables in the regressions of tables 2 and 3 are either (the natural logarithm of) usual hourly wages or hours usually worked per week. The former is calculated as the ratio of usual earnings per week to usual hours worked per week.

Tables 2 and 3 summarise the regression coefficients on dummy variables for computer use at work and Internet use at work. A value of one is assigned to the computer use dummy variable when respondents answered 'Yes' to the following question: (in 1989, 93 and 1997) "Do you directly use a computer at work?" or (in 2001) "Do you use a computer at your main job?". In the CPS questionnaire a computer is defined as a desktop 
terminal or PC with a keyboard and a monitor. A value of one was assigned to the Internet use dummy variable when respondents answered 'Yes' to the following question: (in 1997) “Do you use the Internet (or other on-line service) at work?", (in 1998 and 2000) "Where do you use the internet? At work?", or (in 2001) “At work, do you connect to the Internet or use E-mail?". However, these questions were only asked of respondents who were at work in the previous week (or with a job, but absent), and who, in the 1998, 2000 and 2001 surveys, answered yes to the questions (in 1998 and 2000) "Do you use the Internet outside the home?" or (in 2001) "Do you use a computer at your main job?"

Following Autor et al. (1998), the samples in the table 2 and 3 regressions were restricted to respondents who were (a) at work in the previous week (or with a job, but absent from work), (b) aged 18-65 inclusive, (c) earning more than $\$ 1.50$ per hour and less than $\$ 250$ per hour. Following these restrictions, sample sizes for the years 1989, 1993, 1997 , 1998, 2000 and 2001 were 13,393, 13,395, 12,440, 12,292, 12,599 and 14,630 respectively. We did not use CPS weights in any of the results in this paper. 


\section{References}

Autor, D. (2001), 'Wiring the Labor Market', Journal of Economic Perspectives, Vol. 15, Issue 1 (Winter) pp. 25-40.

Autor, D., Levy, F. and Murnane, R. (2000), 'Upstairs, Downstairs: Computer-Skill Complementarity and Computer-Labor Substitution on Two Floors of a Large Bank', NBER Working Paper 7890, September.

Autor, D., Krueger, A. and Katz, L. (1998), 'Computing Inequality: Have Computers Changed the Labor Market?', Quarterly Journal of Economics, Vol.113, No 4, November, pp. 1169-1214.

Cappelli, P. (2000), 'Computers, Work Organization, and Wage Outcomes', NBER Working Paper 7987, October.

Card, D. and DiNardo, J. (2002), 'Skill Biased Technological Change and Rising Wage Inequality: Some Problems and Puzzles', NBER Working Paper 8769, February.

Centre for Economic Performance, London School of Economics (2001), 'Conference on Unions and Internet', May.

Darlington, R. (2000), 'The Creation of the E-Union: the Use of ICT by British Unions', given at Internet Economy Conference at the Centre for Economic Performance, London School of Economics on 7 November, http://members.tripod.co.uk/rogerdarlington/E_union.html

Delaney J. T., Fiorito, J. and Jarley, P. (2000), 'The Adoption of Information Technology by US National Unions', Industrial Relations, 55 (3), pp. 451-476.

Diamond, W. and Freeman, R. B. (2002), 'Will Unionism Prosper in Cyber-Space? The Promise of the Internet for Employee Organisation', British Journal of Industrial

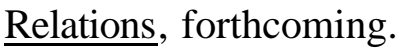

Diamond, W. and Freeman, R. B. (2001), 'The British Workplace Representation and Participation Survey', CEP mimeo, London.

DiNardo, J. and Pischke, S. (1997), 'The Returns to Computer Use Revisited: Have Pencils Changed the Wage Structure Too?', 'Quarterly Journal of Economics, Vol. 112, February, pp. 291-303.

Enhance Media (2002), 'National Online Recruitment Audience Survey Results', April, www.enhancemedia.co.uk.

Farber, H. (1995), 'Are Lifetime Jobs Disappearing? Job Duration in the United States: 1973-1993', NBER Working Paper 5014, February. 
Freeman, R. B. and Rodgers, J. (2002), 'Open Source Unionism: Beyond Exclusive Collective Bargaining', Spring, Vol. 5, No 4 (http://www.workingusa.org/).

Greer, C. (2001), 'E-Voice: How Information Technology is Shaping Life Within Unions', Journal of Labor Research, in press.

Guyer, L. (2001), 'www.allianceibm.org: real world experiences of online organising', presented at Unions and the Internet Conference, London, May 21-22.

Hartford, B. (2001), 'Riding the Internet', presented at Unions and the Internet Conference, London, May 21-22.

Kuhn, P. and Skuterude, M. (2001), 'Does Internet Job Search Reduce Unemployed Workers' Jobless Durations', Santa Barbara Working Paper 20'02.

Kuhn, P. and Skuterude, M. (2000), 'Internet and Traditional Job Search Methods', Monthly Labor Review, October.

Krueger, A. (1993), 'How Computers Have Changed the Wage Structure?', Quarterly Journal of Economics, February, pp. 33-60.

Krueger, A. (2000), personal communication, email September 14.

Lee, E. (1996), 'The Labour Movement and the Internet: the New Internationalism', Pluto Press: London.

Mason, P. (2001), 'ReedNUJ.org: How Workplace Activists used the Internet in a WhiteCollar Union Recognition Campaign', discussion comments, Unions and the Internet Conference, London, May 21-22.

Neumark, D. and Reed, D. (2002), 'Employment Relationships in the New Economy', NBER Working Paper 8910, April.

Progressive Policy Institute 2002 State New Economy Index http://www.neweconomyindex.org/states/,

Quah, D. (2000a), 'Internet Cluster Emergence', European Economic Review, 44, pp. 10321044, May.

Quah, D. (2000b), 'The Weightless Economy: in Whose Interest?', CentrePiece, Spring, Vol. 5, No. 1, Centre for Economic Performance, London School of Economics, pp. 28-30.

Schulman, A. (2001), 'The Extent of Systematic Monitoring of Employee e-Mail and Internet Use', www.privacyfoundation.org/workplace/technology/extentpf.html

Shostak, A. (1999), CyberUnion: Empowering Labor Through Computer Technology, M. E. Sharpe, Inc. 
Shostak, A. (1999), 'Organising via CyberUnions: Can $21^{\text {st }}$ Century CyberUnions be Created in Time?', www.cyberunions.net/articles/orgviacu.html, M. E. Sharpe: Armonk, (NY).

US Department of Commerce (2000), Digital Economy 2000, http://www.esa.doc.gov/de2000.pdf

US Department of Commerce (2002a), Digital Economy 2002, http://www.esa.doc.gov/508/esa/DIGITALECONOMY2002.htm

US Department of Commerce (2002b), A Nation Online, February, http://www.ntia.doc.gov/ntiahome/dn/

Whitfield, D. (2001), 'UNISONdirect: a Trade Union 999 Service', presented at Unions and the Internet London May 11.

Workthing (2001), $2^{\text {nd }}$ Wave, Online Recruitment and Employment Survey (www.workthing.com) 


\section{CENTRE FOR ECONOMIC PERFORMANCE \\ Recent Discussion Papers}

557 R. B. Freeman

556 M. Gutti] rrez-DomPnech

555 H. Gospel

J. Foreman

554 S. Machin

553 J. Blanden

S. Machin

552 D. Devroye

R. B. Freeman

551 M. Guadalupe

550 G. Duranton

549 S. Redding

A. J. Venables

548 T. Bayoumi

M. Haacker

547 A. B. Bernard

S. Redding

P. K. Schott

H. Simpson

546 M. GutiPrez-Doml nech

545 S. Nickell

S. Redding

J. Swaffield

544 S. Machin

A. Manning

J. Swaffield
Institutional Differences and Economic Performance Among OECD Countries

The Impact of the Labour Market on the Timing of Marriage and Births in Spain

The Provision of Training in Britain: Case Studies of Inter-Firm Coordination

Factors of Convergence and Divergence in Union Membership

Cross-Generation Correlations of Union Status for Young People in Britain

Does Inequality in Skills Explain Inequality of Earnings Across Advanced Countries?

The Hidden Costs of Fixed Term Contracts: the Impact on Work Accidents

City Size Distribution as a Consequence of the Growth Process

Explaining Cross-Country Export Performance: International Linkages and Internal Geography

It's Not What You Make, It's How You Use IT:

Measuring the Welfare Benefits of the IT Revolution Across Countries

Factor Price Equalization in the UK?

Employment Penalty After Motherhood in Spain

Educational Attainment, Labour Market Institutions and the Structure of Production

Where the Minimum Wage Bites Hard: the Introduction of the UK National Minimum Wage to a Low Wage Sector 
543 R. Belfield

D. Marsden

542 C. A. Pissarides

541 M. Amiti

C. A. Pissarides

540 G. Duranton

H. G. Overman

539 D. Metcalf

538 F. Collard

R. Fonseca

R. MuZoz

537 C. L. Mann

E. E. Meade

536 M. Manacorda

E. Moretti

535 D. Quah

534 D. Quah

533 R. Dickens

A. Manning

532 S. Machin

A. Manning

531 R. Lydon

A. Chevalier

530 A. Bryson
Matchmaking: the Influence of Monitoring

Environments on the Effectiveness of Performance

Pay Systems

Consumption and Savings With Unemployment Risk:

Implications for Optimal Employment Contracts

Trade and Industrial Location with Heterogeneous

Labor

Testing for Localisation Using Micro-Geographic

Data

Unions and Productivity, Financial Performance and Investment: International Evidence

Spanish Unemployment Persistence and the Ladder Effect

Home Bias, Transactions Costs, and Prospects for the Euro: A More Detailed Analysis

Intergenerational Transfers and Household Structure. Why Do Most Italian Youths Live With Their Parents?

One Third of the World's Growth and Inequality

Matching Demand and Supply in a Weightless Economy: Market Driven Creativity With and Without IPRs

Has the National Minimum Wage Reduced UK Wage Inequality?

The Structure of Wages in What Should be a

Competitive Labour Market

Estimates of the Effect of Wages on Job Satisfaction

The Union Membership Wage Premium: An

Analysis Using Propensity Score Matching

To order a discussion paper, please contact the Publications Unit

Tel 02079557673 Fax 02079557595 Email info@cep.lse.ac.uk Web site http://cep.lse.ac.uk 